\title{
Latitude Observations at Paris Observatory Prior to the ILS
}

\author{
Suzanne Débarbat \\ DANOF/UMR8630-CNRS, Observatoire de Paris \\ 61, avenue de l'Observatoire, 75014 - Paris, France
}

\begin{abstract}
Latitude observations performed at the Paris Observatory from its beginning in 1667 are recalled together with the results mentionned in archives and publications of the time.
\end{abstract}

On the occasion of the bicentenary of the Paris Observatory Le Verrier, in 1867, recalled what must be considered as the first measurement of latitude for that place: "Les mathématiciens (Picard, La Hire) se transportèrent donc sur le lieu, le 21 juin. Ils tirèrent une méridienne et huit alimuths (sic) avec tout le soin que leur pouvaient inspirer des conjectures si particulières. Ils trouvèrent la hauteur méridienne du Soleil à $64^{\circ} 41^{\prime}$ au moins, ce qui donne pour la hauteur du pôle à l'observatoire $48^{\circ} 49^{\prime} 30^{\prime \prime}$ en supposant que la vraie déclinaison du soleil fût de $23^{\circ} 30^{\prime}$ et la réfraction à cette hauteur d'une demi-minute seulement". This measurement was followed by others during the subsequent centuries up to the ILS creation in 1899 , and of course later.

\section{17th Century Paris Observatory Latitude}

This measurement was made with a 6 -foot ${ }^{1}$ sextant in iron, having its limb in copper, and alidade equipped with pinholes. This sextant had been made under the supervision of Roberval (1602-1675). The following months the astronomers made experiments replacing the pinholes by a refractor as made previously, in 1634 , by Morin (1583-1656); but they added the micrometer Picard (16201682) and Auzout (1622-1691) devised in 1666. For accurate measurements Picard installed later a quadrant against a wall of the oriental tower at the level he had an apartment. From his measurements he concluded that the latitude of the southern façade of the building, now named "Bâtiment Perrault", was $48^{\circ} 50^{\prime} 10^{\prime \prime}$.

This was also the result obtained shortly after the arrival of Jean-Dominique Cassini (1625-1712) in Paris (March 1669) : "Le 21 décembre 1669 Messieurs Cassini et Picard trouvèrent qu'à la Bibliothèque du Roy [...] et que par conséquent à l'Observatoire (que l'on bâtissoit alors, \& qui est plus méridional de $0^{d}, 1^{\prime}, 50^{\prime \prime}$ que la Bibliothèque du Roy) la hauteur apparente du Pole étoit de $48^{d}, 51^{\prime}, 10^{\prime \prime}$ : d'où ôtant une minute à cause de la réfraction, il restoit pour la vraïe hauteur du Pole à l'Observatoire, $48^{d}, 50^{\prime}, 10^{\prime \prime}$. This value is also the

\footnotetext{
${ }^{1}$ The foot, as well as the French "pied", includes 12 inches (in French "pouces") but the inch is equal to $2.54 \mathrm{~cm}$ while the "pouce" is $2.71 \mathrm{~cm}$
} 
result given by Cassini when he delivered, at the "Académie des sciences", a talk entitled "S'il est arrivé du changement dans la hauteur du Pole, ou dans le cours du Soleil ?" on 1693 July 31. Cassini begins: "Le déréglement que l'on a remarqué dans les Saisons depuis quelques années, les fréquens tremblemens de terre arrivez en divers lieux, ont fait soupçonner qu'il s'étoit fait quelque changement dans l'économie du monde; \& il y a eu même des Astronomes qui ont crûu s'être aperçûs que depuis quelques années le pole avoit considérablement changé de hauteur". After some historical considerations Cassini mentions observations having given various values " $48^{\circ} 39^{\prime} ; 48^{\circ} 45^{\prime} ; 48^{\circ} 50^{\prime} ; 48^{\circ} 55^{\prime}$..." and comes to the present time : "A Paris on a aussi remarqué en peu de temps une variation sensible de la hauteur du Pole."

Cassini also mentions results obtained from the Pole Star leading to the following values, when taking into account $1^{\prime}$ for the refraction:

$\begin{array}{ll}1671 \text { December } 11 & 48^{\circ} 50^{\prime} 40^{\prime \prime} \\ \text { 1672 January } 10 & 48^{\circ} 50^{\prime} 32^{\prime \prime} 1 / 2 \\ \text { 1672 January } 14 & 48^{\circ} 50^{\prime} 25^{\prime \prime} \\ \text { 1688 January (?) } & 48^{\circ} 50^{\prime} 30^{\prime \prime} \\ \text { 1691 December } 21 & 48^{\circ} 50^{\prime} 0^{\prime \prime} \\ \text { 1692 Nov./Dec. } & 48^{\circ} 50^{\prime} 15\end{array}$

Cassini is considering the error to be of the order of a few seconds only, and the refraction being $52^{\prime \prime}$ or $1^{\prime}$ from his tables. He also considers four possible causes of variations being larger than a few arseconds: - les "instrumens (...) souffrent de tems en tems des altérations sensibles" - la "difficulté qui se rencontre à estimer les parties des minutes" - les "réfractions irrégulières qui se font dans l'air" - du "changement dans la direction du fil perpendiculaire des instrumens, \& que ce changement soit plus sensible en certains lieux de la terre qu'en d'autres". Cassini's conclusion for the latitude of the Paris Observatory: "Il est néanmoins très-probable que de temps en temps il arrive effectivement quelque petite variation dans la hauteur du Pole: mais elle se rétablit dans la suite, \& elle n'excède point deux minutes". [...] Depuis vingt-deux ans qu'il y a que l'Observatoire Royal est bâti, on y a observé quantié de fois la hauteur du Pole; mais on n'y a point remarqué de changement qui ne soit au-dessous de deux minutes."

What the astronomers were observing during the last quarter of the 17 th century was indeed a combination of two phenomena to be discovered later by Bradley (1693-1762): aberration (1726), which had been suspected by Picard, (just before his death, from his observations of the Pole Star he observed mostly for latitude) and nutation (1746), both phenomena having an effect of the same order in magnitude, about $20^{\prime \prime}$, but with different elliptical consequences.

\section{18th Century Paris Observatory Latitude}

The instrumentation did not change for at least half a century. For the beginning of the 18 th century the value $48^{\circ} 50^{\prime} 30^{\prime \prime}$ is seen, larger than Picard's result. This circumstance is the same when Jacques Cassini (1677-1756) finds $48^{\circ} 51^{\prime}$ (sic) $9^{\prime \prime}$ while, in 1744, César-François Cassini (1714-1784) de Thury will give $48^{\circ} 50^{\prime} 12^{\prime \prime}$, that is to say, the same value as Picard's result within the limits of the errors. 
But it is true to say that, from 1743 , the Observatory has a large 6 -foot quadrant made in 1732 by Lenoir (1744-1832). It is apparently the one for which Cassini de Thury wrote that he asked Lenoir to enlarge the 6-foot sextant into a quadrant. This new quadrant is still in use by the year 1785, equipped with two refractors, and with which the latitude is found to be $48^{\circ} 50^{\prime} 12^{\prime \prime}$ in 1786 , and $48^{\circ} 50^{\prime} 14^{\prime \prime}$ in 1787 . This value will be considered as the one to be used for the reduction of further observations of celestial objects. The result is, again, smaller than those for the beginning of the century, but of the order of Picard's and Cassini's predecessor's results.

By that time a new instrument appeared : the repeating circle by Borda (1733-1799). This instrument was employed first for the 1787 linkage of the Paris and Greenwich Observatories. In 1790, 1791 and 1792 Jean-Dominique Cassini (1748-1845) made experiments for the determination of declination of stars and was convinced of the fact that this small instrument (about one foot for the circle and the refractors) was more accurate than the previous large quadrants due to the repetition. Careful measurements of the Paris Observatory latitude were made with such an instrument by Méchain (1744-1804) mostly through the Pole Star observed "à Paris en hyver d'abord et ensuite en été" at the then Observatoire impérial. This was made on the occasion of the operation Méchain performed with Delambre (1749-1822) for the determination of the length of the meter. Méchain and Delambre had apparently noticed variations in the latitude and the idea was that they were different according to the season. The manuscript by Méchain is in the Archives of the Paris Observatory; some data are different from those published by Delambre in 1810, after Méchain's death. Méchain made an incredible number of determinations, 1670 in total between 1798 December 9 and 1799 February 6 for winter, and between 1799 May 17 and August 23 for summer.

The differences could attain several arcseconds. At the Paris Observatory the astronomers were beginning to notice latitude variations, originated indeed by the polar motion.

\title{
3. 19th Century Paris Observatory Latitude
}

The instruments will change with the new century. Cassini IV had shown the value of the full circles. After the small ones, of the Borda-Lenoir types, larger ones are made. Laplace (1749-1827) got a Reichenbach (München) with a full circle. Others were installed in the east wing of the Paris Observatory, specially built for that purpose, to replace the mural quadrants. Latitude measurements made with a Gambey (1787-1847) circle and a Fortin (1750-1831) circle are performed at the beginning of the fifties. Comparing observers:

\author{
$48^{\circ} 50^{\prime} 11^{\prime \prime} 85$ (Fortin circle) by Mauvais (1809-1854) \\ $48^{\circ} 50^{\prime} 11^{\prime \prime} 59$ (Gambey circle) by Laugier (1812-1872) \\ $48^{\circ} 50^{\prime} 10^{\prime \prime} 56$ Yvon Villarceau (1813-1883), (small portable instrument)
}

Yvon Villarceau is not satisfied with these results.

Between 1856 and 1861, 900 latitude observations give the following results : 
1856 January 1 - 1857 September 17: $48^{\circ} 50^{\prime} 11^{\prime \prime} 80$

1857 December 17 - 1860 January 16: $48^{\circ} 50^{\prime} 11^{\prime \prime} 61$

1860 March 10 - 1861 December 31: $\quad 48^{\circ} 50^{\prime} 11^{\prime \prime} 71$ values:

Other results are given, from 1857 up to 1862, under the form of annual

$\begin{array}{ll}\text { 1857: } & 48^{\circ} 50^{\prime} 11^{\prime \prime} 79 \\ \text { 1858: } & 48^{\circ} 50^{\prime} 12^{\prime \prime} 00 \\ \text { 1859: } & 48^{\circ} 50^{\prime} 11^{\prime \prime} 74 \\ 1860: & 48^{\circ} 50^{\prime} 12^{\prime \prime} 04 \\ 1861: & 48^{\circ} 50^{\prime} 11^{\prime \prime} 62 \\ 1862: & 48^{\circ} 50^{\prime} 11^{\prime \prime} 56\end{array}$

From all the results Yvon Villarceau adopts for the latitude and for the period $48^{\circ} 50^{\prime} 11^{\prime \prime} 71$. The following year, 1863, between February and March a new comparison is made, under the form of differences: Laugier - YV $\left(+00^{\prime \prime} 63\right)$, Mauvais - YV $\left(+1{ }^{\prime \prime} 29\right), 1856 / 1862$ - YV $(+1$ " 15$)$. Yvon Villarceau does not understand why the differences are so large, and does not admit that it is due to his small instrument he had properly controlled.

The same year, 1863, a great meridian circle by Secrétan-Eichens was installed; tests and new comparisons are made. The values obtained are: $48^{\circ} 50^{\prime}$ $11 " 49,11^{\prime \prime} 57,11^{\prime \prime} 70,13 !^{\prime \prime} 32, \ldots$ Not satisfying again. Having noticed some seasonal variations, Yvon Villarceau asked Le Verrier (1811-1877) to request the monthly means calculated over the past six years $1856-1862$ at the Gambey circle, specially devoted to latitude measurements. The results are the following:

Excès sur la moyenne

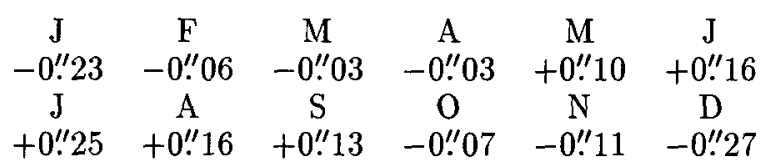

The conclusion by Yvon Vilarceau is: "D'après cela, on pourrait s'attendre à des différences de 0.5 environ entre les latitudes obtenues en janvier et celles obtenues en juillet". And later: Nous ne hasarderons pas d'hypothèse sur ce singulier résultat, qui a besoin d'ailleurs d'être confirmé par de nouvelles déterminations".

Having this six years of monthly means in 1962 Guinot analysed six years of latitude observations at the Paris Observatory given each twentieth of the year, averaging the data in a similar way, month by month. To finalize the comparison, a smoothing curve was placed among Yvon Villarceau's data and an adjustment, according to the time coordinate, made between the two resulting curves.

Apparently Yvon Villarceau was seeing the polar motion combination of the annual term and the Chandler wobble to be detected later (1891) by Chandler (1846-1913) in the US and Küstner (1856-1936) in Berlin. During that time the Paris Observatory astronomers procured a more powerful meridian circle, in 1876 , being aware of a better quality for their circles. But this is another story. 


\section{The French and the non-discoveries included in latitude variations}

From what we know now about the activity of the Paris Observatory astronomers during the period preceding the creation of ILS, it is clear that they would have difficulties discovering some of the astronomical phenomena they had noticed in their latitude results. By the end of the 17th century Picard had fixed a very clever and up-dated programme for astrometry at the Paris Observatory; unfortunately he died in 1682. But during that time Cassini I was engaged in physical observations of the planets of the solar system with main discoveries known all over the world; his name has now been given to a space mission voyaging to Saturn. With his son, Cassini was asked by the King to map the country, a task which was the "grand oeuvre" of Cassini III under the following King and during the XVIIIth century. Doing that, they realized the best map of the time, being the origin of the complete map for Europe, made under the same principles in different countries. For France this map was the one employed, by the end of the XVIIIth century, to decide of the shape of the modern structure named "départements".

Nevertheless, astrometry was not abandoned; even after the discovery of aberration and nutation, Paris astronomers were still seeing variations in the position of the Pole Star. By the XIXth century, the variations of latitude were again noticed mostly on the occasion of a new map for France. Yvon Villarceau and Le Verrier had shown that the coordinates of the main towns were no longer accurate enough. The Paris Observatory latitude, besides the regular job of astronomers, was also carefully studied as a test for instruments to be employed during the campaigns in the country. On that occasion Yvon Villarceau made the careful study examined in this paper, but later he was employed for other purposes, including the development of chronometric measurements. On the other hand, after Le Verrier's death he was replaced by Amiral Mouchez (18211792), who was engaged in a renovation of the Paris Observatory, including the creation of a "Service d'astrophysique", the launching of the "Carte du Ciel", and the development of time signals. Meanwhile the polar motion was discovered and France was not at the correct latitude to be included in the service which is, at present, celebrated in Cagliari.

\section{References}

Manuscrits de l'Observatoire de Paris : A 2-4-18, E 2-9, F 3-13-25.

Annales de l'Observatoire de Paris : Observations, tomes I à IV, XIII à XIX; Mémoires, tomes 1 à 8 .

Comptes rendus de l'Académie des sciences, tome 65.

Guinot B., "La variation de la latitude à Paris." Bull. astron., tome XXIV. 